\title{
PROFIL GURU SD DALAM KEGIATAN BELAJAR MENGAJAR DI MASA PANDEMI COVID-19
}

\author{
Novi Yuni Mayangsari ${ }^{1}$, Septi Budi Sartika ${ }^{2}$ \\ noviyuni634@ gmail.com ${ }^{1,}$ septibudi1@ umsida.ac.id ${ }^{2}$ \\ Prodi Pendidikan Guru Sekolah Dasar, Fakultas Psikologi dan Ilmu Pendidikan, \\ Universitas Muhammadiyah Sidoarjo ${ }^{1}$ \\ Prodi Pendidikan IPA, Fakultas Psikologi dan Ilmu Pendidikan, \\ Universitas Muhammadiyah Sidoarjo ${ }^{2}$
}

\begin{abstract}
Abstrak: Penelitian ini bertujuan untuk mendeskripsikan profil guru SD dalam kegiatan belajar mengajar di masa pandemi Covid-19. Fokus penelitian ini mengarah pada guru, siswa, dan wali murid kelas 1 SD Muhammadiyah 2 Sidoarjo mengenai kegiatan belajar mengajar di masa pandemi covid-19. Penelitian ini menggunakan penelitian kualitatif jenis fenomenologi yaitu mengungkap fakta yang terjadi tentang kegiatan belajar mengajar guru SD di masa pandemi Covid-19. Teknik pengumpulan data yang digunakan yaitu angket. Teknik analisis data menggunakan model Miles \& Hubberman (2014) yang meliputi reduksi data, penyajian data, verifikasi dan kesimpulan. Pengecekan keabsahan data menggunakan triangulasi sumber, yaitu guru, siswa, dan wali murid. Hasil penelitian menunjukkan bahwa profil guru SD dalam kegiatan belajar mengajar di masa pandemi covid-19 bahwa hanya ada satu aspek yang belum tercapai yaitu membuat diskusi melalui forum diskusi, namun untuk aspek yang lain seperti: memberikan modul,memberikan bahan ajar, memberi tugas, menilai tugas, memberikan umpan balik serta mereview pembelajaran sudah tercapai. Penelitian selanjutnya diharapkan menggunakan teknik wawancara, sehingga akan diperoleh hasil penelitian yang lebih mendalam.
\end{abstract}

Kata kunci: profil guru SD, kegiatan belajar mengajar, pandemi covid-19

\section{PRIMARY SCHOOL TEACHER'S PROFILE LEARNING TO TEACH DURING COVID-19 PANDEMIC}

\begin{abstract}
This research aims to describe the primary school teacher's profile in teaching and learning activities during the Covid-19 pandemic. The focus of this research leads to teachers, students, and parents of grade 1 students in SD Muhammadiyah 2 Sidoarjo about teaching activities during the covid-19 pandemic. This research uses qualitative research of phenomenology type that reveals the facts that occur about the learning activities of teaching primary school teachers during of pandemic Covid-19. The data collection technique used is a questionnaire. Data analysis techniques using the Miles \& Hubberman models (2014) include data reduction, data
\end{abstract}


Novi Yuni Mayangsari, Septi Budi Sartika. Profil Guru SD dalam Kegiatan Belajar... display, verification and conclusions. Checking the validity of data using the triangulation of sources, namely teachers, students, and parents. The results showed that the primary school teacher's profile in teaching and learning activities during the covid19 pandemic that there is only one aspect that has not been achieved is making discussions through discussion forums, but for other aspects such as: providing modules, providing teaching materials, giving assignments, assessing tasks, providing feedback and reviewing learning has been achieved. Further research is expected to use interview techniques, so that more in-depth research results will be obtained.

Keywords: primary school teacher's profile, learning to teaching from home, covid-19 pandemic

\section{PENDAHULUAN}

Belajar pada hakikatnya ialah suatu kegiatan yang dilakukan secara sadar oleh seseorang yang menghasilkan perubahan tingkah laku pada diri sendiri, baik dari segi sikap, pengetahuan, maupun keterampilan (Pane \& Daposang, 2017). Selama berlangsung kegiatan belajar terjadi proses interaksi antar siswa dan sumber belajar, dan yang menjadi fasilitator adalah seorang guru (Rohmalina, 2017). Para ahli mengemukakan pengertian belajar dengan persamaan dan perbedaan pada unsur kata dan kalimat dan meletakkan pada kata perubahan secara nyata. Secara tersirat, belajar mengandung makna perubahan, perubahan yang dikehendaki oleh pebelajar. Belajar bukan perihal mengingat, tetapi mengalami. Hasil belajar bukan dari penguasaan latihan melainkan perubahan perilaku (Hamalik, 2016). Jadi, hakikat belajar dapat diartikan sebagai perubahan perilaku, belajar bukan suatu tujuan tetapi merupakan suatu proses untuk mencapai suatu tujuan yang sebenarnya.

Pembelajaran yang berkualitas hanya dapat diwujudkan oleh guru yang memiliki kemampuan unggul dan motivasi yang tinggi dalam melaksanakan kewajibannya (Sumar \& Razah, 2016). Demikian pula sebaliknya, jika pembelajaran yang dikelola guru tidak berkualitas, hasilnya juga tidak akan berkualitas. Belajar mengajar melibatkan beberapa pihak, yaitu peserta didik, guru, tujuan pembelajaran, isi pelajaran, metode mengajar, media dan evaluasi (Nurdyansyah, 2018). Tujuan pembelajaran adalah perubahan perilaku dan tingkah laku yang positif dari peserta didik setelah mengikuti kegiatan belajar mengajar, seperti: perubahan yang secara psikologis akan tampil dalam tingkah laku yang dapat diamati melalui alat indera oleh orang lain baik tutur katanya, motorik dan gaya hidupnya.

Semua orang yakin bahwa guru memiliki andil yang sangat besar terhadap keberhasilan pembelajaran di sekolah. Guru sangat berperan dalam membantu perkembangan peserta didik untuk mewujudkan tujuan hidupnya secara optimal (Sulistyorini, 2018). Keyakinan ini muncul karena manusia adalah makhluk lemah, yang dalam perkembangannya senantiasa membutuhkan orang lain, sejak lahir, bahkan pada saat meninggal. Semua itu menunjukkan bahwa setiap orang membutuhkan orang 
Novi Yuni Mayangsari, Septi Budi Sartika. Profil Guru SD dalam Kegiatan Belajar... lain dalam perkembangannya (Ibda, 2015), demikian halnya dengan orang tua yang mendaftarkan anaknya ke sekolah, pada saat itu juga ia menaruh harapan terhadap guru, agar anaknya dapat berkembang secara optimal. Untuk mencapai tujuan tersebut, dibutuhkan sosok guru yang memiliki kreativitas mengajar yang tinggi dan dalam berbagai situasi dan kondisi lingkungan.

Kondisi lingkungan saat ini cukup rumit, yaitu merebaknya wabah Covid-19 ke Indonesia pada pertengahan Maret 2020, memberikan dampak besar dan perubahan pada segala aspek kehidupan. Salah satunya adalah merubah tatanan pendidikan, mulai dari tingkat sekolah dasar sampai perguruan tinggi (Riani \& Handayani, 2020), sehingga dianjurkan untuk melaksanakan kegiatan belajar mengajar dari rumah guna meminimalisir penularan wabah Covid-19 (Murafikhah, 2020). Hal ini menjadi tantangan tersendiri bagi beberapa guru dan siswa. Lantaran pembelajaran daring tidak pernah dilakukan sebelumnya. Guru harus mampu mengendalikan konsentrasi anak didiknya walaupun tidak bertemu secara langsung (Santosa \& Santosa, 2020). Hal ini tentu dapat dilakukan para guru yang memiliki visi misi yang tepat dengan tetap menanamkan empat kompetensi guru dalam dirinya yaitu pedagogik, keterampilan, profesional dan kepribadian (Sulfemi, 2019). Meskipun proses pembelajaran daring tidak seefektif proses pembelajaran langsung, sebaiknya guru harus mencari cara dan menyiasati supaya kualitas pembelajaran tetap baik (Irawan dkk, 2020). Untuk menghasilkan kualitas belajar yang terbaik, menurut Makariem, Menteri Pendidikan dan Kebudayaan mengatakan "guru harus terus berinovasi dan meningkatkan metode pengajaran setiap saat” (Kemendikbud, 2015).

Pembelajaran yang inovatif di masa pandemi dapat dilakukan dengan berbagai cara oleh guru. Salah satunya mampu mengkolaborasikan berbagai metode, di antaranya guru bertindak sebagai tutor jarak jauh, murid sebagai media yang dapat belajar daring dengan bimbingan guru dan orang tua (Lase, 2019). Orang tua difungsikan sebagai tutor pengganti guru di sekolah yang memantau perkembangan belajar anak di rumah (Kurniawan, 2018). Hal yang paling penting, komunikasi antara guru, anak didik, dan orang tua di masa pandemi ini harus benar-benar terjalin. Jika komunikasi tidak berjalan, maka proses kegiatan belajar mengajar di masa pandemi ini akan dianggap gagal.

Komunikasi yang terjalin dalam kegiatan belajar mengajar antara guru, siswa, dan orang tua selama pandemi covid-19 akan berdampak pada perkembangan anak (Dewi, 2020). Hal ini sesuai dengan pendapat Makariem: seperti halnya murid, inilah saatnya guru dan orang tua berinovasi dengan melakukan banyak tanya, banyak coba, dan banyak karya". Dengan demikian pentingnya melihat perubahan dan mau berubah, pentingnya bergerak dan aktif, tidak monoton merupakan cita-cita bersama.

Berdasarkan hasil observasi yang telah dilakukan, guru di SD Muhammadiyah 2 Sidoarjo menerapkan kegiatan belajar mengajar dari rumah selama pandemi covid-19. Peneliti bermaksud untuk mendeskripsikan profil guru SD dalam kegiatan belajar mengajar dari rumah di masa pandemi covid-19. 
Novi Yuni Mayangsari, Septi Budi Sartika. Profil Guru SD dalam Kegiatan Belajar...

\section{METODE}

Metode penelitian menggunakan pendekatan penelitian kualitatif tipe fenomenologi yaitu penelitian yang dilakukan pada kondisi alamiah, langsung ke sumber data dan peneliti adalah instrumen kunci atau gambar sehingga tidak menekankan pada angka (Sugiyono, 2016). Validasi instrumen perlu dilakukan dengan tujuan agar mendapatkan data yang valid dalam penelitian (Arikunto, 2014). Penelitian ini menggunakan instrumen pengumpulan data yaitu angket. Angket merupakan teknik pengumpulan data dengan cara mengajukan pertanyaan tertulis untuk dijawab oleh responden (Sugiyono, 2016). Angket merupakan kumpulan pertanyaan-pertanyaan yang tertulis yang digunakan untuk memperoleh informasi dari responden tentang pertanyaan yang diberikan oleh peneliti, angket bersifat tertutup dengan penilaian menggunakan skala likert. Angket disebarkan melalui aplikasi google form yang kemudian di link google form dibagikan kepada guru, siswa, dan wali murid kelas 1 di SD Muhammadiyah 2 Sidoarjo. Teknik analisis data menggunakan model Miles \& Huberman (2014), yang meliputi reduksi data, penyajian data, verfikasi dan kesimpulan. Pengecekan keabsahan data menggunakan triangulasi sumber, yaitu guru, siswa, dan wali murid. Triangulasi dapat diartikan sebagai pengecekan data dari berbagai sumber dengan berbagai cara serta waktu atau pemeriksaan kebsahan data yang memanfaatkan sesuatu yang lain di luar data itu untuk keperluan pengecekan atau sebagai pembanding data (Moleong, 2011). Angket untuk mengungkap kegiatan belajar mengajar ini telah divalidasi oleh pakar/ ahli dan dinyatakan valid dan layak digunakan. Menurut Yusup (2018), instrumen yang valid akan mendapatkan data yang benar sehingga memperoleh kesimpulan yang sebenarnya.

\section{HASIL}

Berikut akan disajikan data dari angket untuk ketiga sumber, yaitu guru, siswa, dan wali murid kelas I SD Muhammadiyah 2 Sidoarjo:

Tabel 1. Hasil Angket Kegiatan Belajar Mengajar

\begin{tabular}{lllcccc} 
& & & \multicolumn{3}{c}{ Respons } \\
\cline { 3 - 6 } No & Indikator & Aspek yang diteliti & Guru & Siswa & $\begin{array}{c}\text { Wali } \\
\text { Murid }\end{array}$ & Keterangan \\
\hline 1 & $\begin{array}{l}\text { Perencanaan } \\
\text { Pembelajaran }\end{array}$ & $\begin{array}{l}\text { Memberikan buku } \\
\text { panduan/ modul/ } \\
\text { RPP. }\end{array}$ & $\sqrt{ }$ & $\sqrt{ }$ & $\sqrt{ }$ & Kredibel \\
& $\begin{array}{l}\text { Memberikan bahan } \\
\text { ajar berupa buku } \\
\text { paket/ LKS. }\end{array}$ & $\sqrt{ }$ & $\sqrt{ }$ & $\sqrt{ }$ & Kredibel \\
& $\begin{array}{l}\text { Memberikan kisi- } \\
\text { kisi soal penugasan/ } \\
\text { kuis/ ujian. }\end{array}$ & $\sqrt{ }$ & $\sqrt{ }$ & $\sqrt{ }$ & Kredibel \\
& & & & \\
\hline
\end{tabular}


Novi Yuni Mayangsari, Septi Budi Sartika. Profil Guru SD dalam Kegiatan Belajar...

\begin{tabular}{|c|c|c|c|c|c|c|}
\hline \multirow[t]{2}{*}{2} & \multirow[t]{2}{*}{$\begin{array}{l}\text { Pelaksanaan } \\
\text { Pembelajaran }\end{array}$} & $\begin{array}{l}\text { Menyampaikan } \\
\text { materi pembelajaran. }\end{array}$ & $\sqrt{ }$ & $\sqrt{ }$ & $\sqrt{ }$ & Kredibel \\
\hline & & $\begin{array}{l}\text { Membentuk diskusi } \\
\text { kelompok melalui } \\
\text { forum diskusi. }\end{array}$ & - & - & - & $\begin{array}{l}\text { Kredibel, } \\
\text { tetapi tidak } \\
\text { valid }\end{array}$ \\
\hline \multirow[t]{4}{*}{3} & \multirow[t]{4}{*}{$\begin{array}{l}\text { Evaluasi } \\
\text { pembelajaran }\end{array}$} & $\begin{array}{l}\text { Memberikan tugas/ } \\
\text { kuis/ ujian baik } \\
\text { kelompok atau } \\
\text { mandiri. }\end{array}$ & $\sqrt{ }$ & $\sqrt{ }$ & $\sqrt{ }$ & Kredibel \\
\hline & & $\begin{array}{l}\text { Memeriksa tugas/ } \\
\text { kuis/ ujian baik } \\
\text { kelompok atau } \\
\text { mandiri. }\end{array}$ & $\sqrt{ }$ & $\sqrt{ }$ & $\sqrt{ }$ & Kredibel \\
\hline & & $\begin{array}{l}\text { Memberikan umpan } \\
\text { balik mengenai hasil } \\
\text { penilaian tugas/ } \\
\text { kuis/ ujian. }\end{array}$ & $\sqrt{ }$ & $\sqrt{ }$ & $\sqrt{ }$ & Kredibel \\
\hline & & $\begin{array}{l}\text { Mereview atau } \\
\text { merangkum } \\
\text { pembelajaran. }\end{array}$ & $\sqrt{ }$ & $\sqrt{ }$ & $\sqrt{ }$ & Kredibel \\
\hline
\end{tabular}

Berdasarkan Tabel 1, hasil angket kegiatan belajar mengajar dari rumah di masa pandemi covid-19 sebagai berikut:

1. Aspek yang dilihat dari hasil kegiatan belajar mengajar dari aspek 1 memberikan buku panduan atau modul RPP guru, siswa dan wali murid:

Guru sebagai pelaksana pendidikan diharapkan dapat mampu untuk mempersiapkan perangkat pembelajaran yang bertujuan untuk memaksimalkan hasil belajar siswa. Pembelajaran merupakan bagian terpenting dari pembelajaran seperti rpp dan silaus pembelajaran. Silabus disiapkan oleh pemerintah sehingga guru dapat mengembangkan silabus tersebut. RPP merupakan perangkat pembelajaran yang wajib disusun oleh guru agar pembelajaran terlaksana dengan baik. Perencanan pembelajaran sebagai proses pengambilan keputusan dan hasil berpikir secara rasional tentang sarana dan tujuan pembelajaran. Yang meliputi serangkaian perilaku dan kegiatan yang harus dilaksanakan sebagai upaya pencapaian tujuan dengan memanfaatkan segala potensi dan sumber belajar yang ada.

2. Aspek yang dilihat dari hasil kegiatan belajar mengajar dari aspek 2 memberikan bahan ajar berupa buku paket/ LKS

Lembar Kerja Siswa (LKS) merupakan suatu bahan ajar cetak berupa lembar kertas yang berisi materi, ringkasan, dan petunjuk pelaksanaan tugas pembelajaran yang harus dikerjakan oleh siswa dan mengacu pada kompetensi dasar yang harus dicapai. Fungsi dan tujuan dari penyusunan lembar kerja siswa yaitu sebagai bahan ajar yang mempermudah siswa untuk memahami materi yang mengandung unsur 
Novi Yuni Mayangsari, Septi Budi Sartika. Profil Guru SD dalam Kegiatan Belajar... perkembangan kognitif yang berisi prosedur kerja untuk meningkatkan pemahaman materi dan keterampilan. Dalam hal ini peneliti mengobservasi bahwa hasil guru untuk memberikan bentuk lembar LKS kepada siswa dan memberikan pemahaman kepada wali murid sangat kredibel. Hasil yang dilihat memuat delapan unsur yaitu judul, kompetensi dasar yang dicapai, waktu penyelesaian, peralatan atau bahan yang diperlukan untuk menyelesaikan tugas, informasi singkat, langkah kerja, tugas yang dilakukan dan laporan yang harus dikerjakan.

3. Aspek yang dilihat dari hasil kegiatan belajar mengajar dari aspek 3 memberikan kisi-kisi soal penugasan/ kuis/ ujian

Kisi-kisi adalah suatu format berupa matriks yang memuat pedoman untuk menulis soal atau merakit soal menjadi suatu tes penilaian guru. Fungsi dari kisi-kisi ini adalah sebagai pedoman dalam penulisan soal atau dalam melakukan perakitan tes. Dalam penelitian dan observasi yang dilakukan oleh peneliti hasil kredibel. Dalam hal ini kisi-kisi atau penugasan sesuai dengan silabus dan RPP mata pelajaran yang sudah disiapkan oleh guru dan telah disampaikan sebelumnya. Sesuai dengan hasil penelitian yaitu kredibel artinya guru, siswa dan wali murid mengetahui bahwa guru memberikan kiki-kisi soal penugasan kuis/ ujian.

4. Aspek yang dilihat dari hasil kegiatan belajar mengajar dari aspek 4 menyampaikan materi pembelajaran

Menyampaikan materi pembelajaran adalah salah satu hal yang paling penting dalam kegiatan belajar mengajar, guru wajib menyampaikan materi kepada siswa agar siswa dapat memahami pembelajaran yang sedang dipelajari. Pada hasil pengamatan menyampaikan materi pembelajaran sangat kredibel yang artinya apa yang guru sampaikan sudah sesuai dengan KD, Indikator yang telah ditetapkan.

5. Aspek yang dilihat dari hasil kegiatan belajar mengajar dari aspek 5 membentuk diskusi kelompok melalui forum diskusi

Dalam aspek diskusi terkait dengan pendapat yang disampaikan siswa rasional atau tidak dan terkait dengan yang disampaikan siswa. Aspek ini mengalamai tidak ada peningkatan yang baik. Siswa tidak mampu menyampaikan pendapat dengan rasional dan disertai alasan yang tepat. berdasarkan deskripsi dan catatan lapangan hasilnya kredibel namun hasil beum tercapai yang artinya guru belum membentuk forum diskusi yang juga tidak pernah diketahui oleh siswa dan wali murid.

6. Aspek yang dilihat dari hasil kegiatan belajar mengajar dari aspek 6 memberikan tugas/ kuis/ ujian baik kelompok/ mandiri

Dalam aspek memberikan tugas baik kelompok atau mandiri berjalan dengan kredibel. Yang artinya siswa, guru, dan wali murid dapat berkotribusi dengan baik. Dalam memberikan tugas, guru tidak serta merta memberikan soal, tapi berupa gambar agar siswa dapat memahami kuis atau ujian yang diberikan oleh guru.

7. Aspek yang dilihat dari hasil kegiatan belajar mengajar dari aspek 7 memeriksa tugas/ kuis/ ujian baik kelompok atau mandiri 
Novi Yuni Mayangsari, Septi Budi Sartika. Profil Guru SD dalam Kegiatan Belajar...

Dalam hal ini juga penting dalam kegiatan belajar mengajar. Setelah guru memberikan tugas dan dikerjakan oleh siswa kemudian tugas guru adalah memeriksa hasil yang sudah dikerjakan oleh siswa. Dari data diatas hasinya yaitu kredibel artinya guru sudah melakukan pemeriksaan terhadap tugas/ kuis/ ujian baik kelompok atau mandiri, hal itu juga telah dikerjakan oleh siswa dan diketahui oleh guru.

8. Aspek yang dilihat dari hasil kegiatan belajar mengajar dari aspek 8 memberikan umpan balik mengenai hasil penilaian tugas/ kuis/ ujian

Dalam hal umpan balik ini guru setelah memberikan dan melakukan pegukuran mengenai pembelajaran. Maka guru akan memberikan evaluasi akhir, dimana proses evaluasi ini dijadikan sebagai bahan pertimbangan implementasi bahasa jawa. Adapun tujuan dari evaluasi untuk memperoleh hasil yang akurat dan objektif. Informasi tersebut berupa mengenai program, hasil pencapaian, serta pemanfaatan hasil evaluasi yang difokuskan untuk program itu sendiri. Dari hasil pengamatan dan catatan kaki yang dilakukan peneliti adalah kredibel.

9. Aspek yang dilihat dari hasil kegiatan belajar mengajar dari aspek 9 mereview atau merangkum pembelajaran

Pemberian rangkuman sebagai salah satu komponen dalam strategi belajar mengajar mempunyai fungsi dan peranan yang sangat penting. ialah satu keterampilan dalam proses belajar mengajar yang harus dimiliki oleh seorang guru adalah dapat memilih berbagai strategi dalam mengajar dan menggunakan strategi tersebut sesuai dengan tujuan pengajaran yang hendak dicapai, walaupun pada dasarnya tidak satupun strategi belajar mengajar yang selalu cocok untuk berbagai tujuan pengajaran. Dalam merangkum pembelajaran, hasil pengamatan tidak kredibel dari segi siswa dan wali murid.

\section{PEMBAHASAN}

Pada penelitian ini telah menghasilkan beberapa aspek yang telah dilakukan oleh guru dan siswa serta diketahui oleh wali murid. Sesuai dengan data di atas bahwa pada aspek 1 hasilnya yaitu kredibel artinya guru sudah memberikan buku panduan/ RPP. Rencana Pelaksanaan Pembelajaran (RPP) adalah salah satu kegiatan yang dilakukan guru sebelum melaksanakan pembelajaran di kelas. Di samping itu rencana pelaksanaan pembelajaran adalah rancangan pembelajaran mata pelajaran per unit yang akan diterapkan guru dalam pembealajaran di kelas. Selanjutnya (Mulyasa, 2015) mengatakan RPP dibuat dalam rangka pedoman guru dalam mengajar sehingga pelaksanaannya bisa lebih terarah, sesuai dengan KD yang telah ditetapkan. Dalam penyusunan RPP, seorang guru harus mampu menguasai secara teoritis unsur-unsur yang ada di dalam RPP. Selain bermanfaat bagi guru sebagai panduan, RPP juga bermanfaat untuk memprediksi keberhasilan pembelajaran, mengantisipasi kemungkinan yang akan terjadi, memanfaatkan sumber belajar secara optimal, dan mengorganisir kegiatan pembelajaran secara sistematis. RPP yang dihasilkan guru 
Novi Yuni Mayangsari, Septi Budi Sartika. Profil Guru SD dalam Kegiatan Belajar... ditentukan dari pengetahuan dan pemahaman tentang tagihan Kurikulum 2013 yang dimiliki seorang guru.

Pada aspek 2 hasilnya kredibel, artinya guru memberikan bahan ajar berupa LKS kepada siswa. Menurut Gazali (2016), ketersediaan bahan ajar seperti LKS sangat diperlukan untuk menunjang proses pembelajaran dan meningkatkan prestasi belajar siswa. Dengan demikian, dapat dinyatakan bahwa bahan ajar berupa LKS penting untuk menunjang kegiatan belajar mengajar.

Pada aspek 3 hasilnya kredibel, artinya guru memberikan kisi-kisi soal yang meliputi tugas/ kuis/ ujian kepada siswa. Menurut April (2019), jika semua soal yang dibuat oleh guru sesuai dengan kisikisi maka kualitas soal akan semakin baik. Untuk mewujudkan kondisi tersebut tentu tidak mudah, karena tuntutannya adalah guru harus mampu menyusun kisi-kisi dengan baik. Kisi-kisi soal menjadi penting karena dari soal yang diberikan akan mampu memberi gambaran ketercapaian pembelajaran.

Pada aspek 4 hasilnya kredibel, artinya guru menyampaikan materi pembelajaran. Menurut Ausubel (dalam Anitah, 2007), belajar verbal yang bermakna atau belajar bermakna melalui penggunaan interaksi aktif antara guru dengan siswa, pembelajaran ini menekankan pada ekspositori yaitu guru menyajikan materi secara eksplisit dan terorganisasi dan siswa menerima serangkaian ide yang disajikan guru dengan cara yang efisien. Materi pembeljaran yang terorganisasi dengan baik akan memudahkan siswa dalam memahami keterkaitan materi.

Pada asepk 5 hasilnya tidak kredibel, guru tidak membentuk diskusi kelompok. Hasil temuan menyatakan bahwa guru kesulitan mengkoordinasikan siswa untuk online secara bersamaan karena kondisi siswa yang tidak sama satu sama lain. Metode diskusi kelompok meliputi: membentuk kelompok, menjelaskan konsep permasalahan yang harus dipecahkan kelompok, setiap kelompok menginventarisasi/ mencatat alternatif jawaban hasil didiskusikan, selanjutnya guru bersama siswa membuat kesimpulan atau guru melengkapi jawaban siswa, sampai materi pelajaran tuntas (Juniati, 2017). Menurut Slavin (2006), kegiatan berkelompok dapat membantu siswa mereview dan menguasai materi pelajaran. Dengan memperhatikan hal tersebut, diskusi menjadi penting karena dengan diskusi akan ada tambahan wawasan dan pengetahuan.

Pada asepek 6 hasilnya kredibel, artinya guru memberikan tugas/ kuis/ ujian kepada siswa. Menurut Refindasari (2015), pemberian tugas, kuis, dan ujian pada pembelajaran online penting untuk mengukur kemampuan siswa dalam memahami materi yang disampaikan oleh guru. Tugas/ kuis/ ujian merupakan bagian dari pengukuran ketercapaian sebuah proses pembelajaran.

Pada aspek 7 hasilnya kredibel, artinya guru memeriksa tugas/ kuis/ ujian siswa. Menurut Kusuma (2020), fase mengevaluasi dapat diartikan sebagai memeriksa proses pelaksanaan strategi, hasil belajar yang telah dicapai, serta memeriksa kesesuaian strategi dengan jenis tugas belajar yang dihadapi. Dengan demikian memeriksa suatu tugas/ kuis/ ujian merupakan bagian dari evaluasi pembelajaran. 
Novi Yuni Mayangsari, Septi Budi Sartika. Profil Guru SD dalam Kegiatan Belajar...

Pada aspek 8 hasilnya kredibel, artinya guru memberikan umpan balik kepada siswa dalam pembelajaran. Menurut Harjasuganda (2008), feedback atau disebut umpan balik berfungsi memberikan motivasi, reinforcement atau punishment, dengan keuntungan antara lain: 1) mendorong siswa untuk terus berlatih, 2) mencerminkan perilaku guru yang efektif, 3) membantu siswa untuk menilai penampilan (kemampuan) yang tidak bisa dilihat dan dirasakannya sendiri, dan 4) mendorong guru untuk menilai seberapa relevansi antara aspek-aspek pembelajaran dengan tingkat kemampuan siswa dalam menguasai tugas gerak (bahan ajar) seperti yang diinginkan oleh gurunya. Umpan balik sangat penting dalam sebuah kegiatan belajar mengajar.

Pada aspek 9 hasilnya kredibel, artinya guru melakukan review/ merangkum materi pelajaran yang telah disampaikan. Guru bersama siswa merangkum, meringkas, dan mereview pelajaran sehingga diharapkan mampu menambah pemahaman siswa akan materi yang telah disampaikan (Umam, 2012). Kegiatan merangkum dan mereview menjadi penting dilakukan sehingga pemahaman siswa bertambah.

\section{SIMPULAN}

Berdasarkan hasil dan pembahasan, maka dapat disimpulkan bahwa profil guru SD dalam kegiatan belajar mengajar di masa pandemi covid-19 terdapat 8 aspek yang terlaksana yaitu memberikan buku panduan/ modul/ RPP, memberikan bahan ajar berupa buku paket/ LKS, memberikan kisi-kisi soal penugasan/ kuis/ ujian, menyampaikan materi pembelajaran, memberikan tugas/ kuis/ ujian baik secara kelompok maupun mandiri, memeriksa tugas, memberikan umpan balik pembelajaran serta mereview atau merangkum pembelajaran, namun ada 1 aspek yang belum terlaksana yaitu membuat diskusi kelompok melalui forum diskusi. Penelitian selanjutnya diharapkan mampu mengungkap seluruh aspek kegiatan belajar mengajar walaupun dalam kondisi yang terbatas.

\section{UCAPAN TERIMA KASIH}

Peneliti mengucapkan terimakasih kepada kedua orang tua, suami dan anak yang telah memberikan motivasi untuk menyelesaikan artikel ini, dosen pembimbing dan penguji skripsi yang telah memberikan masukan dan saran untuk perbaikan skripsi, serta seluruh civitas akademika Universitas Muhammadiyah Sidoarjo dan pihak-pihak yang tidak dapat disebutkan satu-persatu.

\section{DAFTAR RUJUKAN}

Anitah, S. (2007). Strategi Pembelajaran. Jakarta: Universitas Terbuka.

April, S. (2019). Meningkatkan kemampuan guru dalam menyusun kisi-kisi soal dengan metode pendampingan pola "OCF" di SDN Yanti Jogoroto. Jurnal Dinamika Manajemen Pendidikan, 4(1), 17-24. 
Novi Yuni Mayangsari, Septi Budi Sartika. Profil Guru SD dalam Kegiatan Belajar...

Arikunto, Suharsimi. (2014). Dasar-dasar Evaluasi Pendidikan (Edisi Revisi). Jakarta. Bumi Aksara.

Dewi, W. A. F. (2020). Dampak Covid-19 terhadap implementasi pembelajaran daring di Sekolah Dasar. Edukatif: Jurnal Ilmu Pendidikan, 2(1), 55-61.

Gazali, R. Y. (2016). Pengembangan bahan ajar matematika untuk siswa SMP berdasarkan teori belajar ausubel. Pythagoras, 11(1), 183.

Harjasuganda, D. (2008). Pengembangan Konsep Diri yang Positif pada Siswa SD Sebagai Dampak Penerapan Umpan Balik (Feedback) dalam Proses Pembelajaran Penjas. Dalam Jurnal Pendidikan Dasar Nomor, 9(8), 4-5.

Ibda, F. (2015). Perkembangan kognitif: teori jean piaget. Intelektualita, 3(1).

Irawan, E., Arif, S., Hakim, A. R., Fatmahanik, U., Fadly, W., Hadi, S., ... \& Hidayati, N. (2020). Pendidikan Tinggi Di Masa Pandemi: Transformasi, Adaptasi, dan Metamorfosis Menyongsong New Normal. Zahir Publishing.

Juniati, E. (2017). Peningkatkan hasil belajar matematika melalui metode drill dan diskusi kelompok pada siswa kelas VI SD. Scholaria: Jurnal Pendidikan dan Kebudayaan, 7(3), 283-291.

Kementrian Pendidikan dan Kebudayaan. Jakarta 2015

Kurniawan, K. (2018). Perhatian Orang Tua Terhadap pembelajaran Bahasa Arab Peserta Didik di Sekolah Dasar Islam Terpadu (SDIT) Smart School Makassar (Doctoral dissertation, Universitas Islam Negeri Alauddin Makassar).

Kusuma, D. A. (2020). Dampak Penerapan Pembelajaran Daring Terhadap Kemandirian Belajar (Self-Regulated Learning) Mahasiswa Pada Mata Kuliah Geometri Selama Pembelajaran Jarak Jauh Di Masa Pandemi Covid-19. Teorema: Teori dan Riset Matematika, 5(2), 169-175.

Lase, D. (2019). Pendidikan di Era Revolusi Industri 4.0. SUNDERMANN: Jurnal Ilmiah Teologi, Pendidikan, Sains, Humaniora dan Kebudayaan, 1(1), 28-43.

Lexy J.Moleong, Metodologi Penelitian Kualitatif. (Bandung: PT.Remaja Rosdakarya,2011),195

Miles, M. B., Huberman, A. M., \& Saldaña, J. (2014). Qualitative data analysis: A methods sourcebook. 3rd.

Mufarikhah Umar, Lulus., \& Nursalim, M. (2020). Studi Kepustakaan Tentang Dampak Wabah Covid-19 Terhadap Kegiatan Belajar Mengajar Pada Siswa Sekolah Dasar (SD). Jurnal BK UNESA, 11(4).

Mulyasa. (2015). Guru dalam Implementasi Kurikulum 2013. Bandung: Rosda (http://www.dostoc.com/does/1991556/4_270228) (Diunduh 23 Agustus 2020)

Nurdyansyah, N. (2018). Pengembangan Bahan Ajar Modul Ilmu Pengetahuan Alambagi Siswa Kelas Iv Sekolah Dasar. Universitas Muhammadiyah Sidoarjo.

Oemar Hamalik, Proses Belajar Mengajar (Jakarta : Remaja Rosdakarya 2016)

Pane, A., \& Dasopang, M. D. (2017). Belajar dan pembelajaran. Fitrah: Jurnal Kajian Ilmu-Ilmu Keislaman, 3(2), 333-352.

Revindasari, F. (2015). Pengembangan sistem pengelolaan materi dan kuis berbasis moodle yang interaktif dan komunikatif (Doctoral dissertation, Universitas Negeri Malang).

Riani, N., \& Handayani, N. S. (2020). Dampak Stres Kerja Pustakawan Pada Masa Pandemi Covid-19 Terhadap Layanan Perpustakaan Perguruan Tinggi. Fihris: Jurnal Ilmu Perpustakaan dan Informasi, 15(1), 97-114. 
Novi Yuni Mayangsari, Septi Budi Sartika. Profil Guru SD dalam Kegiatan Belajar...

Santoso, D. H., \& Santosa, A. (2020). Covid-19 Dalam Ragam Tinjauan Perspektif. LPPM Mercubuana.

Slavin, R. E. (2006). Educational Psychology Theory and Practice Eight Edition. In USA: Library of congres Cataloging in Publication Data.

Sugiyono Metode Penelitian Pendidikan Pendekatan Kuantitatif, Kualitatif dan R\&D (Bandung:Alfabeta, 2013)

Sulfemi, W. B. (2019). Kemampuan Pedagogik Guru.

Sulistiyorini.'Evaluasi Pendidikan Dalam Meningkatkan Mutu Pendidikan".2018.Yogyakarta:Teras.

Sumar, W. T., \& Razak, I. A. (2016). Strategi pembelajaran dalam implementasi kurikulum berbasis soft skill. Deepublish.

Umam, S. (2012). Implementasi Pembelajaran IPS Terpadu di SMP dan MTS SeKecamatan Belik dan Wakumpul Kabupaten Pemalang (Doctoral dissertation, Universitas Negeri Semarang).

Wahab, R. (2012). Reformulasi Inovasi Kurikulum: Kajian Life Skill Untuk Mengantarkan Peserta Didik Menjadi Warga Negara Yang Sukses. Ta'dib: Journal of Islamic Education (Jurnal Pendidikan Islam), 17(02), 217-254.

Yusup, F. (2018). Uji validitas dan reliabilitas instrumen penelitian kuantitatif. Tarbiyah: Jurnal Ilmiah Kependidikan, 7(1). 